\title{
Child seating position and restraint use in three
}

\section{states}

\author{
Susan A Ferguson, JoAnn K Wells, Allan F Williams
}

\begin{abstract}
Objective-Because of risks from deploying airbags to children in front seats, extensive publicity has been aimed at getting them restrained and in rear seats. The objective of this study was to assess restraint use and seating positions among children in vehicles with and without airbags.

Method-Surveys were conducted in cities in Michigan, North Carolina, and Texas 1998. Restraint use and seating position were noted for all children, as well as their estimated age, driver belt use, airbag presence, and vehicle license plate number.

Results-Fewer children were observed in the front seats of vehicles with passenger airbags $(24 \%)$ than in vehicles without them $(36 \%)$. Most of the children seated in front were ages $7-12(44 \%-61 \%)$, followed by 3-6 year olds $(29 \%-35 \%)$. Very few children ages 0-2 were seated in front (5\%$12 \%$ ). The overwhelming majority of children ages 0-2 were restrained. However, children ages 3-6 seated in the front were least likely to be restrained and most likely to be improperly restrained. Restraint use was higher when the driver was belted, but about $30 \%$ of 3-6 year olds were unrestrained even with a belted driver.

Conclusions-Efforts should continue to educate parents about the importance of correct restraint use and rear seating for children, particularly once children move from child safety seats into adult belts. Efforts also should be made to enforce the seat belt laws that exist in every state. (Injury Prevention 2000;6:24-28)
\end{abstract}

Keywords: restraints; seating position; motor vehicle crashes

Motor vehicle crash injuries are the leading cause of fatality among children in the United States, resulting in the deaths of more than 2000 children age 12 and younger in $1998 .{ }^{1}$ Although motor vehicle deaths involving children have declined since 1975, most of this decline has been in child pedestrian and bicycle deaths. Whereas child pedestrian and bicycle deaths have declined $67 \%$ since 1975 , passenger vehicle occupant deaths among children age $0-12$ were only $4 \%$ lower in 1997 than in 1975. These trends, however, are not uniform for children of different ages. Analyses of Fatality Analysis Reporting System (FARS) data $^{2}$ indicate that, since 1975 , passenger vehicle occupant death rates per 100000 popula- tion have declined substantially (about 40\%) for children younger than age 3. Death rates have declined $10 \%$ for $3-6$ year olds and increased $9 \%$ for $7-12$ year olds.

Despite mandatory child restraint use laws in every state in the United States, most of the deaths involve children who were riding unrestrained. ${ }^{3}$ In the United States and in other countries, restraint use is typically much higher among young children but declines with age. ${ }^{4-6}$ In the United States in 1996, 85\% of infants were restrained compared with $60 \%$ of $1-4$ year olds and $65 \%$ of $5-15$ year olds.

Where children sit in vehicles also can affect the risk of death in crashes. It has been known for some time that rear seats are safer, ${ }^{7-16}$ and recent research confirms that the risk of dying in a crash is about $30 \%$ lower for children sitting in rear seats compared with the front. ${ }^{12} 17$ Seating position has become an even more important issue for children since the introduction of passenger airbags. As of 1 October 1999, crash investigations have confirmed 84 deaths of infants and children caused by passenger airbag deployments in low severity crashes in the United States. ${ }^{18}$ Moreover, analyses have indicated that children's risk of dying in vehicles with passenger airbags is higher than in vehicles without them. ${ }^{19}$ These deaths have prompted a wave of publicity aimed at getting children seated in the back. Laws in four states (Delaware, Louisiana, North Carolina, and Rhode Island) prohibit children from sitting in the front seat when, for example, a rear seat is available or when a vehicle is equipped with a passenger airbag.

Few studies provide data about children's seating habits. Recent telephone surveys indicate the percentage of children riding in front seats increases with age. ${ }^{20-21}$ Although there is evidence that fewer children are riding in front seats, in 1997 drivers reported $8 \%-16 \%$ of 1-12 year olds still typically rode in front seats of passenger airbag equipped vehicles. ${ }^{21}$ Given that people often under-report behavior that may be socially undesirable, it is likely that more children are riding in front than is indicated by self reports. However, very few observational surveys have been conducted to confirm this. In one study, children traveling in motor vehicles were observed at or near the cities of Boston and New Orleans in the United States and Brussels, Frankfurt, and Paris. Front seat occupancy ranged from $9 \%-22 \%$ of children in the European cities, where laws have been in place for many years requiring children to sit in the rear, compared with about $25 \%$ of children in Boston and New Orleans. ${ }^{22}$
Susan A Ferguson, Vice

President, Research (e-mail:

sferguson@iihs.org) 
The goal of the present study was to investigate where children sit in vehicles and whether the likelihood of being restrained varies with seating position. Also of interest was whether the presence of a passenger airbag affected either seating position or restraint use. There is evidence, some of it using data from crashes, that children are restrained more often when drivers use belts. ${ }^{73-25}$ Thus, driver belt use also was observed.

\section{Methods}

This study was conducted in cities in Michigan, North Carolina, and Texas during the spring and summer of 1998. Each state has child restraint laws that require children to travel in approved child restraint devices, and some permit or require older children to use adult safety belts. The age at which belts can be used instead of child restraints differs among the states. In many states, older children are covered by the adult seat belt laws which may not require belts in the rear seat. ${ }^{26}$

To insure that sufficient infants would be observed to examine seating positions and restraint use, counties in each state were rank ordered by the number of infants in that county according to the 1990 census. The four counties in each state with the greatest infant populations were chosen, and the largest cities in each county were identified as potential sites for observation. Detroit (Wayne, Oakland, and Macomb counties) and Grand Rapids (Kent county) were selected in Michigan. Charlotte (Mecklenburg county), Raleigh (Wake county), Fayetteville (Cumberland county), and Greensboro (Guilford county) were selected in North Carolina. Dallas/Fort Worth (Dallas and Tarrant counties), Houston (Harris county), and San Antonio (Bexar county) were selected in Texas. In North Carolina, observations were conducted in Greenville, not Greensboro, for a better geographic representation that included the coastal region.

Sites were chosen in close proximity to shopping malls, fast food restaurants, daycare centers, etc to maximize the number of children observed. Three observers were positioned at intersections where vehicles came to a stop and that afforded unobstructed views of the right side passenger windows of at least 100-200 vehicles per hour. Observations included all non-commercial vehicles in the adjacent lane. Data were collected during daylight at times when the likelihood of observing children was greatest. Observations were conducted for 13-18 days in each of the three states. Highly trained observers were used in the study, nevertheless training sessions were

Table 1 Percentage of vehicles observed in which children were sitting in front seats by state and passenger airbag status

\begin{tabular}{|c|c|c|c|c|c|c|}
\hline & \multicolumn{2}{|c|}{ Michigan } & \multicolumn{2}{|c|}{ North Carolina } & \multicolumn{2}{|l|}{ Texas } \\
\hline & $\begin{array}{l}\text { Total } \\
\text { vehicles }\end{array}$ & $\begin{array}{l}\% \text { In } \\
\text { front }\end{array}$ & $\begin{array}{l}\text { Total } \\
\text { vehicles }\end{array}$ & $\begin{array}{l}\% \text { In } \\
\text { front }\end{array}$ & $\begin{array}{l}\text { Total } \\
\text { vehicles }\end{array}$ & $\begin{array}{l}\% \text { In } \\
\text { front }\end{array}$ \\
\hline Passenger airbag & 770 & 24 & 757 & 20 & 546 & 25 \\
\hline No passenger airbag & 1286 & 36 & 1203 & 37 & 1179 & 45 \\
\hline All vehicles & 2056 & 32 & 1960 & 31 & 1725 & 38 \\
\hline
\end{tabular}

held in Michigan and Texas until observers were able to estimate the child's age within one year about $90 \%$ of the time.

Each seating position, whether it was occupied, and restraint use for passengers judged to be age 15 or younger was noted. Observers noted whether a child was in a forward or rear facing restraint or using a shoulder belt, and driver belt use. For children using seat belts, it was noted whether the shoulder portion was positioned across the chest or behind the back or under the arm. It was not possible to observe whether children seated in the rear were using lap belts. The ages of occupants judged to be younger than 16 were estimated in years. Also noted were vehicle type, passenger airbag presence (as indicated by the letters SRS or an airbag module cover), and each vehicle's license plate.

If an observer was unable to identify whether a passenger airbag was present, the license plate number was used to obtain the vehicle identification number (VIN) from the state motor vehicle registration file. Passenger airbags presence was unknown in 1006 vehicles. Of these, 156 had no matching vehicle identification information; 427 of the remaining 850 vehicles were found to be equipped with passenger airbags. The vehicle was considered to be equipped with a passenger airbag if an airbag was identified in the vehicle or passenger airbag status was unknown, but the VIN indicated there was an airbag present. A comparison of observer judgment with independent determination of airbag presence using the VIN showed agreement in $95 \%$ of the cases.

\section{Results}

A total of 7725 children were observed in 6013 vehicles. Examination of the restraint use data by each individual year of age revealed that children ages $3,4,5$, and 6 seated in the front had lower restraint use rates than did older or younger children. Thus, analyses combined data for ages 3-6. A total of 1116 children were judged to be infants (younger than age 1), 1683 to be 1-2 years old, 2564 to be 3-6 years old, and 2362 to be $7-12$ years old.

\section{WHERE CHILDREN SIT}

Table 1 shows the percentages of vehicles in each state in which children were observed sitting in front seats. Table 2 shows the distributions by age group. Overall, children were seated in the front in about one third of the vehicles. The majority of children seated in front were older. About $30 \%$ of the children seated in front (range 29\%-35\%) were 3-6 years old and $44 \%-61 \%$ of them were $7-12$ years old. Very few of the children seated in the front were infants ( $<1$ year) or 1-2 year olds $(5 \%-12 \%)$.

Fewer children were observed riding in the front of vehicles with passenger airbags than in vehicles without them (Michigan: $\chi^{2}=11.08$, $\mathrm{p}=0.01$; North Carolina: $\chi^{2}=23.24, \mathrm{p}=0.001$; Texas: $\left.\chi^{2}=9.59, p=0.02\right)$. Regardless of passenger airbag presence, the percentage of children 
Table 2 Percentage distribution of vehicles observed in which children were sitting in front seats by state and estimated age

\begin{tabular}{|c|c|c|c|c|c|c|c|}
\hline \multirow[b]{2}{*}{ State } & \multirow[b]{2}{*}{ Type of vehicles observed } & \multicolumn{5}{|c|}{ Age (years) } & \multirow[b]{2}{*}{$\begin{array}{l}\text { Total } \\
\left(\%{ }^{\star}\right)\end{array}$} \\
\hline & & $\begin{array}{l}<1(\% \text { in } \\
\text { front) }\end{array}$ & $\begin{array}{l}1-2(\% \text { in } \\
\text { front })\end{array}$ & $\begin{array}{l}3-6(\% \text { in } \\
\text { front })\end{array}$ & $\begin{array}{l}7-12(\% \text { in } \\
\text { front })\end{array}$ & $\begin{array}{l}\text { Unknown (\% in } \\
\text { front) }\end{array}$ & \\
\hline \multirow[t]{3}{*}{ Michigan } & Passenger airbag & 2 & 3 & 27 & 69 & 0 & 102 \\
\hline & No passenger airbag & 6 & 7 & 30 & 58 & $<1$ & 102 \\
\hline & All vehicles & 5 & 6 & 29 & 61 & 1 & 102 \\
\hline \multirow{3}{*}{ North Carolina } & Passenger airbag & 3 & 4 & 40 & 50 & 3 & 101 \\
\hline & No passenger airbag & 16 & 11 & 33 & 42 & 1 & 103 \\
\hline & All vehicles & 12 & 9 & 35 & 44 & 2 & 102 \\
\hline \multirow{3}{*}{ Texas } & Passenger airbag & 7 & 4 & 34 & 56 & 0 & 101 \\
\hline & No passenger airbag & 12 & 12 & 32 & 46 & 1 & 102 \\
\hline & All vehicles & 11 & 10 & 32 & 48 & 1 & 102 \\
\hline
\end{tabular}

*Total percentages do not add to 100 because occasionally more than one child was in the front seat.

seated in front generally increased with age (Michigan: $\chi^{2}=10.70, \mathrm{p}=0.001$; North Carolina: $\chi^{2}=18.11, \mathrm{p}=0.001$; Texas: $\chi^{2}=6.90$, $\mathrm{p}=0.009$ ).

Children were not seated in front because there was insufficient room in the rear to accommodate them. Rear seats were unoccupied $70 \%$ of the time. In $19 \%$ of the vehicles there was only one person seated in the rear and in about $4 \%$ of the vehicles there were three or more occupants in the rear seat.

\section{RESTRAINT USE}

Table 3 shows restraint use for children in front and rear seats by estimated age. Children were considered restrained if they were in a rear or forward facing child seat, using a lap/shoulder belt, or using a belt with the shoulder portion behind the back or under the arm. Observers could not see whether children were using lap belts in the rear seat. These are included in the unknowns.

Use rates in North Carolina typically were higher than in the other two states. Overall, restraint use rates among children age $0-12$ were $73 \%$ in North Carolina, $64 \%$ in Michigan, and $63 \%$ in Texas. Front seat restraint use rates were $76 \%$ in North Carolina, $66 \%$ in Michigan, and $67 \%$ in Texas compared with rear seat use rates of $72 \%, 64 \%$, and $61 \%$, respectively.

Young children (age 0-2) were restrained more often when seated in the rear (Michigan: $\chi^{2}=66.65, \mathrm{p}=0.001$; North Carolina: $\chi^{2}=20.64$, $\mathrm{p}=0.001$; Texas: $\left.\chi^{2}=42.17, \mathrm{p}=0.001\right)$. Older children (age 3-12), however, were restrained more often when seated in the front (Michigan: $\chi^{2}=81.25, \mathrm{p}=0.001$; North Carolina: $\chi^{2}=57.35$, $\mathrm{p}=0.001$; Texas: $\left.\chi^{2}=82.81, \mathrm{p}=0.001\right)$. Front seat restraint use was lowest among 3-6 year olds, the ages at which many children are moving out of child safety seats into adult belts, ranging from 55\%-66\% compared with $77 \%-$ $89 \%$ for infants, $64 \%-83 \%$ for $1-2$ year-olds, and $69 \%-79 \%$ for $7-12$ year olds (comparing 3-6 and 7-12 year olds, Michigan: $\chi^{2}=10.51$, $\mathrm{p}=0.001$; North Carolina: $\chi^{2}=10.51, \mathrm{p}=0.001$; Texas: $\left.\chi^{2}=20.22, \mathrm{p}=0.001\right)$. The lower restraint use among 3-6 year olds may be related to the fact that very few children this age who were seated in front were in forward facing restraints or booster seats-only $8 \%$ compared with $29 \%$ seated in the rear.

Restraint use in rear seats typically was lowest among 7-12 year olds (comparing 3-6 and 7-12 year olds, Michigan: $\chi^{2}=2.91, \mathrm{p}=0.09$; North Carolina: $\chi^{2}=29.28, \mathrm{p}=0.001$; Texas: $\left.\chi^{2}=3.48, \mathrm{p}=0.06\right)$. Across the states, $89 \%-98 \%$ of infants and 1-2 year olds were restrained in the rear compared with $42 \%-57 \%$ of $3-6$ year olds and $37 \%-39 \%$ of $7-12$ year olds.

However, the percentage of children restrained in rear seats is underestimated because it was difficult to see whether older children were using lap belts, and was counted as unknown. Among 0-2 year olds, there were very few instances in which restraint use was unknown (less than $2 \%$ of the sample), but restraint use was unknown for $14 \%-23 \%$ of 3-6 year olds and $13 \%-21 \%$ of $7-12$ year olds. If all the 3-12 year olds with unknown restraint use actually were restrained (an unlikely possibility), restraint use would be similar among 3-6 and 7-12 year olds, ranging from $61 \%-$ $83 \%$ and from $65 \%-77 \%$, respectively. However, this rate is still lower than among 0-2 year olds.

Table 3 Percentage of children restrained in front and rear seats by state and estimated age; values are number (\%)

\begin{tabular}{|c|c|c|c|c|c|c|c|c|c|c|c|c|}
\hline \multirow[b]{2}{*}{ Age (years) } & \multicolumn{4}{|l|}{ Michigan } & \multicolumn{4}{|c|}{ North Carolina } & \multicolumn{4}{|l|}{ Texas } \\
\hline & Restrained & None & Unknown & Total & Restrained & None & Unknown & Total & Restrained & None & Unknown & Total \\
\hline \multicolumn{13}{|l|}{ Front seat } \\
\hline$<1$ & $28(82)$ & $6(18)$ & 0 & $34(100)$ & $67(89)$ & $8(11)$ & 0 & 75 (100) & $55(77)$ & $16(23)$ & 0 & $71(100)$ \\
\hline $1-2$ & $25(69)$ & $10(28)$ & $1(3)$ & $36(100)$ & $45(83)$ & $9(17)$ & 0 & $54(100)$ & $44(64)$ & $24(35)$ & $1(1)$ & $69(100)$ \\
\hline $3-6$ & $110(56)$ & $67(34)$ & $20(10)$ & $197(100)$ & $140(66)$ & $49(23)$ & $24(11)$ & $213(100)$ & $123(55)$ & $85(38)$ & $15(7)$ & $223(100)$ \\
\hline $7-12$ & 275 (69) & $112(28)$ & $13(3)$ & $400(100)$ & $213(79)$ & $46(17)$ & $10(4)$ & $269(100)$ & $234(73)$ & $71(22)$ & $14(4)$ & 319 (99) \\
\hline Unknown & $4(100)$ & 0 & 0 & $4(100)$ & $5(45)$ & $3(27)$ & $3(27)$ & $11(99)$ & $4(57)$ & $2(29)$ & $1(14)$ & $7(100)$ \\
\hline \multicolumn{13}{|l|}{ Rear seat } \\
\hline$<1$ & $266(96)$ & $12(4)$ & 0 & $278(100)$ & $366(94)$ & $21(5)$ & $1(<1)$ & $388(99)$ & $240(89)$ & $29(11)$ & $1(<1)$ & $270(100)$ \\
\hline $1-2$ & $569(98)$ & $8(1)$ & $4(1)$ & $581(100)$ & $528(96)$ & $8(2)$ & $12(2)$ & $548(100)$ & $363(92)$ & $28(7)$ & $4(1)$ & $395(100)$ \\
\hline $3-6$ & $315(44)$ & $242(34)$ & $166(23)$ & $723(101)$ & $397(57)$ & $109(16)$ & $187(27)$ & $693(100)$ & $218(42)$ & $205(40)$ & $92(18)$ & $515(100)$ \\
\hline $7-12$ & 225 (39) & 224 (39) & $132(23)$ & $581(101)$ & $138(39)$ & $99(28)$ & $118(33)$ & $355(100)$ & $161(37)$ & $196(45)$ & $81(18)$ & $438(100)$ \\
\hline Unknown & $7(54)$ & 0 & $6(46)$ & $13(100)$ & $19(33)$ & $6(11)$ & $32(56)$ & $57(100)$ & $1(8)$ & $7(58)$ & $4(33)$ & $12(99)$ \\
\hline
\end{tabular}

*Total percentages may not add to 100 due to rounding. 
Table 4 Percentage of children observed using shoulder belts incorrectly ${ }^{\star}$ by state

\begin{tabular}{|c|c|c|c|c|c|c|}
\hline \multirow{2}{*}{$\begin{array}{l}\text { Age } \\
\text { (years) }\end{array}$} & \multicolumn{2}{|c|}{ Michigan } & \multicolumn{2}{|c|}{ North Carolina } & \multicolumn{2}{|l|}{ Texas } \\
\hline & Front & Rear & Front & Rear & Front & Rear \\
\hline $3-6$ & 26 & 2 & 18 & 2 & 22 & 2 \\
\hline $7-12$ & 12 & 2 & 11 & 5 & 10 & 3 \\
\hline Unknown & 0 & 0 & 27 & 11 & 43 & 0 \\
\hline
\end{tabular}

*Shoulder belts used behind the back or under the arm.

Not only were 3-6 year olds least likely to be restrained in front seats, but when restrained by lap/shoulder belts they more often were using the shoulder portion incorrectly, either behind the back or under the arm (table 4). Across the states, $18 \%-26 \%$ of $3-6$ year olds seated in front seats were observed using shoulder belts in this manner compared with $10 \%-12 \%$ of children age 7-12 (Michigan: $\chi^{2}=17.99$, $\mathrm{p}=0.001$; North Carolina: $\chi^{2}=4.95, \mathrm{p}=0.026$; Texas: $\left.\chi^{2}=13.78, \mathrm{p}=0.001\right)$. Overall, restraint use in vehicles with passenger airbags was higher than in vehicles without them, although the patterns of use were essentially the same.

\section{RESTRAINT USE AS A FUNCTION OF DRIVER BELT} USE

This study confirms previous studies that have reported higher restraint use among children when drivers are belted. ${ }^{72-25}$ Among infants and 1-2 year olds traveling with belted drivers, $71 \%-99 \%$ were restrained. Use rates were lowest, 7\%-46\%, among 3-12 year olds traveling with unbelted drivers.

Regardless of driver belt use, use rates in the front typically were lowest among 3-6 year olds. About $70 \%(65 \%-73 \%)$ of $3-6$ year olds were restrained in front when drivers were belted compared with more than $80 \%$ of children of other ages (Michigan: $\chi^{2}=6.03$, $\mathrm{p}=0.014$; North Carolina: $\chi^{2}=18.93, \mathrm{p}=0.001$; Texas: $\left.\chi^{2}=17.14, \mathrm{p}=0.001\right)$. In vehicles with unbelted drivers, only $20 \%-46 \%$ of children age 3-6 were restrained in front seats. Use rates in the rear were lowest among 7-12 year olds riding with unbelted drivers, ranging from $7 \%-16 \%$ across the states. Again, it should be noted that belt use likely is underestimated in rear seats because lap belts were not visible.

\section{Discussion}

In the United States, many children still ride in front seats despite extensive publicity advising that rear seats are safer. Some parents apparently are heeding the message because fewer children of all ages are seated in the front seats of vehicles with passenger airbags than in vehicles without them. These children do not ride in front because rear seats are occupied. In this study, rear seats were unoccupied more than two thirds of the time when children were seated in front, and about $20 \%$ of the time there was only one person seated in the rear. Glass and Graham, using the United States FARS data, reported similar findings. ${ }^{27}$ Fewer children appear to be seated in front in European cities, where laws have been in place requiring them to sit in the rear. ${ }^{22}$ It will be of interest to see whether United States laws pro- hibiting front seat use among children will result in more children in the rear.

Even more children are riding in the front seats of older vehicles not equipped with passenger airbags. This raises the concern that when today's fleet of passenger airbag vehicles ages and reaches the resale market, many more children may be riding in front seats, where they will be at risk of injury from deploying airbags. Concerns have been expressed that children, especially young children, in rear seats distract drivers. However, children also can be a distraction when seated in front. Many studies show the benefits of rear seating for children whether or not a vehicle has a passenger airbag, ${ }^{7-17}$ so efforts should continue to encourage parents and others who transport infants and children to place them in rear seats whenever possible.

When it comes to restraint use, there has been much greater success in getting infants and very young children restrained than older children. ${ }^{4-6}$ Of particular concern is that many 3-6 year olds are riding unrestrained or improperly restrained in front seats. Use rates are higher in vehicles with passenger airbags, but many children still ride unrestrained or improperly restrained in the front seats of these vehicles. In North Carolina, where adult belt use is close to $85 \%$, due in part to a primary belt use law in which drivers can be stopped solely for not using their belts and a very intensive seat belt enforcement program, ${ }^{28}$ still about half of 3-6 year olds in front seats ride unrestrained or improperly restrained. Perhaps it should come as no surprise that about $60 \%$ of the child deaths from deploying airbags in the United States involve children ages 3-6. In Europe and in Canada, where restraint use typically is higher than in the United States, very few children have died as a result of airbag deployments in low speed crashes. A recent paper comparing two groups of children, one consisting of children who died as the result of airbag deployment, and the other of children who sustained only minor injury, found that children who survived were much more likely to use belts. ${ }^{29}$ They were also likely to be older (median age 7.1 years $v 4.9$ years for the children with fatal injuries).

Lower restraint use among children seated in the rear has been found in other countries. ${ }^{6}$ However, the estimates of rear seat restraint use in this study likely substantially underestimate actual use among 3-12 year olds because it was not possible to detect lap belted children in the rear. However, even if all the children for whom belt use was unknown were using belts, use rates among 3-12 year olds still would have been lower than among 0-2 year olds. In this study, children in Michigan and North Carolina were covered by belt use laws when in the rear seat; however, in Texas only children ages 4 and older were covered. ${ }^{27}$

In agreement with earlier reports, ${ }^{72-25}$ this study found that drivers who use belts are more likely to restrain children than those who do not. Yet many children, particularly 3-6 year olds, travel unrestrained even when drivers are belted. Thus, efforts aimed primarily at getting 
drivers belted may help but will not eliminate this problem.

Starting at age 3, many children move from child restraints to adult belts, but many of them do so prematurely. ${ }^{12}{ }^{13}$ In many states, it is permissible to restrain children age 3 and older in adult seat belts. (In fact, in Texas only children ages 1 and younger are required to ride in child seats.) A large number of young children using adult belts are too small for the shoulder belt to fit comfortably and, as a result, many put the shoulder belt behind the back or under the arm. In that event, booster seats should be used to ensure a better seat belt fit.

\section{Implications for prevention}

Parents and others who routinely transport children need to be especially vigilant with younger children to ensure they are properly restrained at all times. Many unrestrained or improperly restrained children in the United States have died as a result of deploying airbags in low speed crashes that typically happen on urban roads, so even short trips can be dangerous for young children who travel unrestrained or improperly restrained in the front seats of vehicles with passenger airbags.

Although all states have mandatory restraint laws for children, adult belt laws often cover children ages 4 and older. In many states, these laws require belt use only for front seat occupants and often allow only secondary enforcement. As a result, police officers cannot stop a vehicle solely if a child is riding unrestrained. Ideally, all children should be covered in all seats by child restraint laws, adult belt laws, or both, and should be subject to primary enforcement. Recently Delaware, Louisiana, North Carolina, and Rhode Island have adopted laws prohibiting children from riding in the front when, for example, a rear seat is available or when a vehicle is equipped with a passenger airbag. ${ }^{27}$ It is not known whether these laws have been effective in increasing the percentage of children who ride in the rear seat.

In the past few years, extensive efforts have been made in the United States and elsewhere to educate parents and others about the importance of correct restraint use and rear seating for children, and enforcement of belt use laws has increased. In Canada, highly visible enforcement programs have been very successful, with belt use for children reaching $85 \%-95 \% .^{5}$ However, the results of this limited survey suggest there is still a long way to go in the United States when it comes to protecting children in motor vehicles.

\footnotetext{
The authors would like to thank Insurance Institute for
Highway Safety staff members Charles M Farmer for his assistHighway Safety staff members Charles $M$ Farmer for his assist-
ance with statistical analysis and Claire Segawa for her assistance with the paper. This work was supported by the assistance with the paper. This work
Insurance Institute for Highway Safety.

Insurance Institute for Highway Safety.
This article is based on a study first reported by the Insurance

This article is based on a study first reporte
Institute for Highway Safety in March 1999.

1 Insurance Institute for Highway Safety. Fatality facts: children. Available at: http://www.highwaysafety.org/
}

safety facts/fatality facts/children.htm. Accessed 23 November 1999

2 National Highway Traffic Safety Administration. Fatality Analysis Reporting System, 1975-97. Washington, DC: US Department of Transportation, 1975-97.

3 National Highway Traffic Safety Administration. Traffic safety facts 1998: children. Available at: http:// www.nhtsa.dot.gov/people/ncsa/pdf/child98.pdf. Accessed 23 November 1999.

4 Washington Consulting Group. National occupant protection use survey (DTNH22-93-D-070096). Washington, DC: Washington Consulting Group, 1997.

5 Transport Canada. Child restraint use in Canada: 1997 survey data. (Leaflet CL9804E.) Ottawa, Ontario: Transport Canada, 1998.

6 European Transport Safety Council. Seat belts and child restraints: increasing use and optimizing performance. Brussels, Belgium: European Transport Safety Council, 1996.

7 Agran P, Castillo D, Winn D. Comparison of motor vehicle occupant injuries in restrained and unrestrained 4-14 yearolds. Accid Anal Prev 1992;24:349-55.

8 Evans L, Frick MC. Seating position in cars and fatality risk. Am $\mathcal{F}$ Public Health 1988;78:1456-8.

9 Huelke DF, Compton CP. The effects of seat belts on injury severity of front and rear seat occupants in the same frontal crash. Accid Anal Prev 1995;27:835-8

10 Huelke DF, Lawson TE. The rear seat automobile passenger in frontal crashes. Proceedings of the 22nd Annual Conference of the American Association for Automotive Medicine. Morton Grove, IL: American Association for Medicine. Morton Grove, IL: Americative Medicine, 1978: 141-50.

11 Johnston C, Rivara F, Soderberg R. Children in car crashes: analysis of data for injury and use of restraints. Pediatrics 1994;93:960-5.

12 National Highway Traffic Safety Administration. Revised estimates of child restraint effectiveness. Washington, DC: US Department of Transportation, 1996.

13 National Transportation Safety Board. The performance and use of child restraint systems, seatbelts, and airbags for children in passenger vehicles (NTSB/SS-9601). Washington, DC: National Transportation Safety Board, 1996.

14 Partyka SC. Lives saved by child restraints from 1982 through 1987. Washington, DC: National Highway Traffic Safety Administration, 1988 .

15 Walsh M, Kelleher-Walsh B, McCullough C. A study of motor vehicle accidents involving children (SAE 962436). Proceedings of the 40th Stapp Car Crash Conference. Warren-
dale, PA: Society of Automotive Engineers, 1996:357-70.

16 Williams AF, Zador PL. Injuries to children in automobiles in relation to seating location and restraint use. Accid Anal Prev 1977;9:69-76.

17 Braver ER, Whitfield RA, Ferguson SA. Seating positions and children's risk of dying in motor vehicle crashes. Inj Prev 1998;4:181-7.

18 National Highway Traffic Safety Administration. Special crash investigations (SCI) program reports. Washington, DC: US Department of Transportation, 1999.

19 Braver ER, Ferguson SA, Greene MA, et al. Reductions in deaths in frontal crashes among right-front passengers in vehicles equipped with passenger airbags. $¥ A M A 1997 ; 278$ : vehicles

20 Insurance Institute for Highway Safety. Parents aware of airbag danger, know older kids should ride in rear seat too. Status Report 1996;31(10):7.

21 Cammisa MX, Ferguson SA. Survey of drivers' attitudes toward airbags and deactivation. Fournal of Traffic Medicine 1998;26:115-24.

22 Segui-Gomez M, Glass R, Graham JD. Where children sit in motor vehicles: a comparison of selected European and American cities. Inj Prev 1998;4:98-102.

23 Edwards J, Sullivan K. Where are all the children seated and when are they restrained? (SAE Technical Paper Series 971550.) Warrendale, PA: Society for Automotive Engineers, 1997.

24 Williams AF. Observed child restraint use in automobiles. Am $\mathcal{F}$ Dis Child 1976;130:1311-17.

25 Stulginskas JR, Verreault R, Pless IB. A comparison of observed and reported restraint use by children and adults. Accid Anal Prev 1985;17:381-6.

26 Insurance Institute for Highway Safety. State laws: child restraint, belt laws - children not covered by safety belt or child restraint laws. Available at: http://www.highwaysafety.org/ safety facts/ state laws/restrain.htm\#notcovered. Accessed safety_facts/ state_laws

27 Glass RJ, Graham JD. Kids at risk: where American children sit in passenger vehicles. Fournal of Safety Research 1999;30: 17-24.

28 Williams AF, Reinfurt DW, Wells JK. Increasing seat belt use in North Carolina. Fournal of Safety Research 1996;27: 33-41.

29 Arbogast KB, Durbin DR, Winston FK. Determinants of injury severity with child exposure to passenger airbag deployment. Child occupant protection in motor vehicle crashes. Bury St Edmunds, United Kingdom: Professional Engineering Publishing Limited, 1999: 71-9. 